\title{
Antimicrobial photodynamic active biomaterials for periodontal regeneration
}

DOI:

10.1016/j.dental.2018.06.026

\section{Document Version}

Accepted author manuscript

Link to publication record in Manchester Research Explorer

\section{Citation for published version (APA):}

Sigusch, B. W., Dietsch, S., Berg, A., Voelpel, A., Guellmar, A., Rabe, U., Schnabelrauch, M., Steen, D., Gitter, B., Albrecht, V., Watts, D. C., \& Kranz, S. (2018). Antimicrobial photodynamic active biomaterials for periodontal regeneration. Dental Materials, 34(10), 1542-1554. https://doi.org/10.1016/j.dental.2018.06.026

\section{Published in:}

Dental Materials

\section{Citing this paper}

Please note that where the full-text provided on Manchester Research Explorer is the Author Accepted Manuscript or Proof version this may differ from the final Published version. If citing, it is advised that you check and use the publisher's definitive version.

\section{General rights}

Copyright and moral rights for the publications made accessible in the Research Explorer are retained by the authors and/or other copyright owners and it is a condition of accessing publications that users recognise and abide by the legal requirements associated with these rights.

\section{Takedown policy}

If you believe that this document breaches copyright please refer to the University of Manchester's Takedown Procedures [http://man.ac.uk/04Y6Bo] or contact uml.scholarlycommunications@manchester.ac.uk providing relevant details, so we can investigate your claim.

\section{OPEN ACCESS}


Antimicrobial photodynamic active biomaterials for periodontal regeneration

B.W. Sigusch ${ }^{1}$, S. Dietsch ${ }^{1}$, A. Berg ${ }^{2}$, A. Völpel ${ }^{1}$, A. Guellmar ${ }^{1}$, U. Rabe ${ }^{1}$, M. Schnabelrauch ${ }^{2}$, D. Steen $^{3}$, B. Gitter ${ }^{3}$, V. Albrecht ${ }^{3}$, D.C. Watts ${ }^{4}$, S. Kranz ${ }^{1}$

${ }^{1}$ Department of Conservative Dentistry and Periodontology, University Hospitals Jena, An der alten Post 4, 07743 Jena, Germany

${ }^{2}$ Biomaterials Department, INNOVENT e.V. Pruessingstrasse 27 B, 07745 Jena, Germany

${ }^{3}$ biolitec research $\mathrm{GmbH}$, Otto-Schott-Str. 15, 07745 Jena, Germany

${ }^{4}$ University of Manchester, School of Medical Sciences, Oxford Road, M13 9PL Manchester, UK

\section{Corresponding author:}

Dr. Stefan Kranz

Department of Conservative Dentistry and Periodontology

An der alten Post 4

07743 Jena, Germany

Phone: +493641934581

Email: Stefan.Kranz@med.uni-jena.de

\section{Conflict of interest:}

None of the above listed authors reported any potential conflict of interest.

\section{Submission declaration and verification:}

The results of the manuscript have not been published elsewhere. The publication was approved by all authors and will not be published in the same form anywhere else. 


\section{Abstract}

\section{Objectives}

Biomaterials for periodontal regeneration may have insufficient mechanical and antimicrobial properties or are difficult to apply under clinical conditions. The aim of the present study was to develop a polymeric bone grafting material of suitable physical appearance and antimicrobial photodynamic activity.

\section{Material and methods}

Two light curable biomaterials based on urethane dimethacrylate (BioM1) and a triarmed oligoester-urethane methacrylate (BioM2) that additionally contained a mixture of $\beta$-tricalcium phosphate microparticles and $20 \mathrm{wt} \%$ photosensitizer mTHPC (PS) were fabricated and analyzed by their compressive strength, flexural strength and modulus of elasticity. Cytotoxicity was observed by incubating eluates and in directcontact to MC3T3-E1 cells. Antimicrobial activity was ascertained on Porphyromonas gingivalis and Enterococcus faecalis upon illumination with laser light (652 nm, 1 x $100 \mathrm{~J} / \mathrm{cm}^{2}, 2 \times 100 \mathrm{~J} / \mathrm{cm}^{2}$ ).

\section{Results}

The compressive strength, flexural strength and elastic modulus were, respectively, 311.73 MPa, 22.81 MPa and 318.85 MPa for BioM1+PS and 742.37 MPa, 7.58 MPa and 406.23 MPa for BioM2+PS. Both materials did not show any cytotoxic behavior. Single laser-illumination $(652 \mathrm{~nm})$ caused total suppression of $P$. gingivalis (BioM2+PS), while repeated irradiation reduced $E$. faecalis by 3.7 (BioM1+PS) and 3.1 (BioM2+PS) log-counts.

\section{Significance}

Both materials show excellent mechanical and cytocompatible properties. In addition, irradiation with $652 \mathrm{~nm}$ induced significant bacterial suppression. The manufactured biomaterials might enable a more efficient cure of periodontal bone lesions. Due to the mechanical properties functional stability might be increased. Further, the materials are antimicrobial upon illumination with light that enables a trans-mucosal eradication of residual pathogens. 
Keywords: biomaterial, laser, photodynamic therapy, periodontitis, periodontal bone regeneration, aPDT, photosensitizer, Enterococcus faecalis, Porphyromonas gingivalis

\section{Antimicrobial photodynamic active biomaterials for periodontal regeneration}

\section{Introduction}

Periodontitis is a chronic and highly prevalent inflammatory disease of bacterial origin that is characterized by a progressive destruction of the alveolar bone, periodontal ligament and root cementum.

To prevent inflammation and further destruction of the periodontal hard and soft tissues, the initial treatment is mainly aimed at the destruction and removal of supraand subgingival microbial biofilms. In general, this is accomplished by a professional dental cleaning followed by mechanical debridement and smoothening of the root surface. The procedure is often accompanied by a systemic administration of antibiotics or local application of antiinfective agents [1-3].

Especially in times of growing antibiotics resistance, the search for alternative antiinfective approaches is of major concern. In periodontitis treatment, measures such as the antimicrobial Photodynamic Therapy (aPDT) are therefore increasingly applied as an adjunct to the common scaling and root planning procedures. In case of aPDT, microbes are lethally damaged by highly reactive oxygen radicals that are formed upon illumination of a so-called photosensitizer (often a deep colored dye) with light of its absorption wavelength [4]. As already shown in numerous studies, aPDT is capable in suppressing oral bacteria and fungi sufficiently [5-12].

However, in periodontitis therapy, patients that have experienced the initial antiinflammatory treatment often suffer from persistent alveolar bone defects and decreased tissue levels [13-15]. In order to support regeneration of the injured periodontium grafting materials might be inserted [16]. These include a whole range of materials such as barrier membranes, autografts, demineralized and freeze-dried bone allografts, bovine-derived xenografts and the combination of membranes and filler substances as well as the local application of growth factors such as Emdogain $®$ or GEM 21S $₫[15,17-19]$.

All of these measures are likely to support periodontal regeneration. But, if the applied materials do not meet the clinical requirements exactly, problems might arise. 
In those cases, the implanted grafts might be rejected, delocalized or encapsulated by fibrous tissue causing a restriction of the materials' biological function [20].

Sometimes, surgeons are also confronted with insufficient mechanical and antibacterial properties or the application of the material is time consuming and to complicated.

However, up to now, there is no grafting material available that unites osteoinductive and -conductive characteristics with local antimicrobial activity and satisfactory physical stability. In this regard, our group already published data showing that polymers of poly(vinyl butyral-co-vinyl alcohol-co-vinyl acetate, urethane methacrylate or functionalized oligolactones are of promising characteristics [21].

Based on these results, the aim of the present study was to design an innovative synthetic grafting material that can easily be applied during periodontal surgery, shows mechanical properties similar to alveolar bone and is of sufficient antimicrobial activity. In order to turn the material antiinfective, the potent photosensitizer metatetra(hydroxyphenyl)chlorin (mTHPC) was incorporated that can be activated by illumination with red light of $652 \mathrm{~nm}$ and already demonstrated efficient antimicrobial activity $[5,7]$. 


\section{Materials and methods}

\section{$2.1 \quad$ Chemicals}

D,L-lactide was purchased from Purac Biochem (Gorinchem, The Netherlands). Urethan dimethacrylate (UDMA), a mixture of two isomeric monomers (Fig. 1) and polyethylene glycol 400 (PEG 400) extended UDMA (P-UDMA) were received from Esstech (Essington, USA).

2-isocyanatoethyl methacrylate (IEM), stannous octoate, dibutyltin dilaurate (DBTL), camphorquinone, ethyl 4-dimethylaminobenzoate and several solvents were obtained from Sigma-Aldrich Chemie (Taufkirchen, Germany).

$\beta$-Tricalcium phosphate ( $\beta$-TCP Cerasorb $\otimes$ ) was supplied by Curasan (Frankfurt am Main, Germany).

\subsection{Photosensitizer mTHPC}

The photosensitizer mTHPC (also known as Temoporfin), which was kindly provided by biolitec research (Jena, Germany), is a very potent second-generation photosensitizer (for its chemical structure: see figure 3 ) and is the active ingredient in the drug Foscan ${ }^{\circledR}$ which is already approved for photodynamic treatment of nonmelanoma skin cancer (biolitec, Jena, Germany). The photodynamic reaction of $\mathrm{mTHPC}$ is activated by irradiation with light of $652 \mathrm{~nm}$.

In the present study, the hydrophobic photosensitizer mTHPC was mixed with ßtricalcium phosphate microparticles (ß-TCP) at a concentration of $20 \mathrm{wt} \%$ and added to the polymeric base materials (also see below). Specimens without photosensitizer and $ß-$ TCP served as controls. The mixture of $\mathrm{mTHPC}$ and $ß-\mathrm{TCP}$ is abbreviated as 'PS' throughout the entire study.

The added mTHPC is expected to generate sufficient antibacterial activity upon irradiation with red laser light at $652 \mathrm{~nm}$, while ß-TCP mainly functioned as porogen and was used as carrier for the photosensitizer. 


\subsection{Biomaterial 1 (BioM1)}

Biomaterial 1 (BioM1) is based on UDMA (Fig. 1) mixed with a photoinitiator system consisting of camphorquinone and ethyl 4-dimethylaminobenzoate in a ratio of 1:1. Both components of the photoinitiator system were applied as 1 molar solution.

For sample preparation, $990 \mathrm{mg}$ UDMA was mixed with $50 \mu \mathrm{l}$ of the photoinitiator system and $10 \mathrm{mg}$ of the mTHPC / ß-tricalcium phosphate mixture (PS).

Specimens without PS served as controls. For these samples, only $40 \mu \mathrm{l}$ of the photoinitiator system was added to the UDMA. Pilot studies have shown that $40 \mu \mathrm{l}$ of the photoinitiator system caused the most efficient polymerization of samples without mTHPC.

On the day of testing, the materials were freshly prepared and stored in the dark at room temperature until use.

\subsection{Biomaterial 2 (BioM2)}

For BioM2, a glycerol oligo-D,L-lactide based tri-armed urethane methacrylate was prepared as a trifunctional monomer in a two-step synthesis.

Briefly, as a first step, ring-opening oligomerization of D,L-lactide in the presence of glycerol was performed followed by end-capping of the terminal hydroxy groups of the tri-armed oligolactone with IEM. The chemical structure of this monomer is shown in Fig. 2. The synthesis of the glycerol-oligo-D,L-lactide was performed similarly as described previously [22]:

Briefly, a mixture of glycerol $(2.5 \mathrm{~g}, 27.15 \mathrm{mmol}), \mathrm{D}$, L-lactide $(58.68 \mathrm{~g}, 407.17 \mathrm{mmol})$ and $140.6 \mu \mathrm{l}(0.43 \mathrm{mmol})$ stannous octoate, in the presence of $6 \mathrm{ml}$ toluene, was stirred under nitrogen at $140^{\circ} \mathrm{C}$. After 30 and $60 \mathrm{~min}$, the stannous octoate solution was repeatedly added and the mixture was stirred for $4 \mathrm{~h}$, cooled to room temperature and dissolved in $50 \mathrm{ml}$ of dichloromethane. The solution was filtered and the crude product was precipitated twice into $700 \mathrm{ml}$ of heptane. Finally, the isolated product was dried under vacuum at room temperature to constant weight.

The glycerol-oligo-D,L-lactide $(8 \mathrm{~g}, 3.55 \mathrm{mmol})$ and $8.4 \mu \mathrm{l}(0.014 \mathrm{mmol})$ DBTL were dissolved in $40 \mathrm{ml}$ of dichloromethane. After 10 minutes, IEM $(1.51 \mathrm{ml}, 10.64 \mathrm{mmol})$ dissolved in $2 \mathrm{ml}$ dichloromethane, was slowly added and the reaction mixture was stirred for $40 \mathrm{~h}$ at $50{ }^{\circ} \mathrm{C}$ under nitrogen. The mixture was cooled to room temperature, extracted twice with $25 \mathrm{ml}$ of $2 \mathrm{~N} \mathrm{NaOH}$ solution and several times with distilled water until neutral $\mathrm{pH}$. The organic layer was dried over $\mathrm{Na}_{2} \mathrm{SO}_{4}$. The solvent 
was evaporated and the resulting residue was dried under vacuum, yield: $8.30 \mathrm{~g}$, (86 $\%)$.

For BioM2 specimen preparation, $790 \mathrm{mg}$ of the tri-armed glycerol-oligolactideurethane methacrylate was mixed with $200 \mathrm{mg}$ P-UDMA, $50 \mu \mathrm{l}$ of the photoinitiator system (refer to 2.3) and $10 \mathrm{mg}$ of the mTHPC / B-tricalcium phosphate mixture (PS). For specimens without PS (controls) only $40 \mu$ of the photoinitiator system was applied as described in 2.3.

The freshly prepared BioM2 with and without PS was stored in the dark at room temperature until use.

\subsection{Analytical methods}

In order to obtain more detailed information about the structural character, IR spectra were recorded in the region of $4000-400 \mathrm{~cm}^{-1}$ using the FTIR spectrometer FTS 175 (Bio-Rad, München, Germany) in ATR (attenuated total reflection) mode. ${ }^{1} \mathrm{H}$ and ${ }^{13} \mathrm{C}$ NMR spectra were performed on a Bruker Avance DRX 500 NMR spectrometer in $\mathrm{CDCl}_{3}$ at $25^{\circ} \mathrm{C}$.

The glass-transition temperature $\left(T_{g}\right)$ was determined by dynamic mechanical analysis (DMA). In brief, particles were chipped off the photo-polymerized specimens and collected $(50 \mathrm{mg})$. Subsequently, the particles were transferred and analyzed using the dynamic mechanical analyzer DMA7e (Perkin Elmer Corporation, Norwalk, USA) in the temperature range between -20 and $200{ }^{\circ} \mathrm{C}$. The heating rate was set to $5 \mathrm{~K} / \mathrm{min}$. The obtained results were adjusted by applying the tangent delta $(\tan \Delta)$. 


\subsection{Specimen preparation and mechanical behavior}

Mechanical tests were performed to obtain information on the compressive strength, modulus of elasticity and flexural strength of the materials with and without PS.

For each test series, 15 specimens containing PS and 15 specimens without PS were prepared. The non-polymerized materials were transferred to silicone molds ( 7 x $5 \mathrm{~mm}$ of cylindrical shape for the compression test; $20 \times 4 \times 5 \mathrm{~mm}$ of rectangular shape for the three-point flexural test) and polymerized using a commercially available dental light curing unit (Profil Lux ${ }^{\circledR}, 590 \mathrm{~mW} / \mathrm{cm}^{2}$, Voco, Cuxhaven, Germany). To ensure total polymerization of the materials each side of the specimen was irradiated 3 times for $20 \mathrm{~s}$. Before testing, excess material was removed and the geometrical dimensions of the specimens were checked.

The compressive strength of the biomaterials was tested using the Instron Testing System 4469 (Instron, Darmstadt, Germany) at a temperature of $25{ }^{\circ} \mathrm{C}$ and a humidity of $50 \%$. The maximum force of the measuring cell was set to $50.00 \mathrm{kN}$ at a loading speed of $12 \mathrm{~mm} / \mathrm{min}$. Beside the compressive strength, the elastic modulus was also determined:

$S_{\text {compression }}=E \bullet e$

where [S] represents the compressive stress, [E] the elastic modulus and [e] the strain. The compressive stress is defined as quotient of the test force $[F]$ and surface $[\mathrm{A}]$ :

$S_{\text {compression }}=\frac{F}{A}$

The strain $[e]$ is defined as ratio between change in length $[\Delta l]$ and initial length of the specimen:

$e=\frac{\Delta l}{l_{0}}$

The elastic modulus was defined as:

$E=\frac{S}{e}$ 
For analyzing the flexural strength a Texture Analyser TA-XT 2i (Stable Micro Systems, Godalming, UK) equipped with a three point bend rig HDP/3PB at a support length of $20 \mathrm{~mm}$ was used. The test was performed at a temperature of $25^{\circ} \mathrm{C}$ and at a humidity of $50 \%$. Results were calculated applying the following formula:

$B=\frac{M}{W}$

The flexural strength $[B]$ is defined as quotient of the flexural moment $[\mathrm{M}]$ and the resistance moment $[\mathrm{W}]$. The flexural moment is defined as:

$M=\frac{F \bullet l}{4}$

where $[\mathrm{F}]$ represents the compressive strength and [l] the support length of the HDP/3PB bend rigs. The resistance moment was obtained as follows:

$W=\frac{a \bullet h^{2}}{6}$

where [a] represents half of the side length and [h] the heights of the specimen. 


\subsection{Water degradation study}

An accelerated degradation test, based upon weight loss of specimens in distilled water at $70{ }^{\circ} \mathrm{C}$, was performed to obtain information about the degradation behavior of the biomaterials in vitro. Cylindrical specimens $(7 \times 7 \mathrm{~mm}, \mathrm{n}=12)$ were fabricated by polymerizing the respective monomers into silicon molds. Each specimen contained $0.5 \mathrm{~g}$ monomer that was mixed with the mTHPC / $\beta$-tricalcium phosphate proportion as described in sections 2.3 and 2.4. Specimens without PS were also formulated. All specimens were light-cured for $60 \mathrm{~s}$ and subsequently rinsed several times with distilled water. The weight of each specimen was recorded.

The degradation test was performed in $5 \mathrm{ml}$ distilled water for 20 weeks at a constant temperature of $70^{\circ} \mathrm{C}$.

The distilled water was changed every 14 days and the weight of the specimens was recorded. At given time points the specimens were removed and dried to a constant weight at $65{ }^{\circ} \mathrm{C}$. Weight loss of the specimens was gravimetrically determined. The experiments were run in triplicate.

\subsection{Cytotoxicity - eluates}

Specimens of BioM1 and BioM2 with and without PS of cylindrical shape $(9 \times 4 \mathrm{~mm}, \mathrm{n}$ $=48$ ) were prepared as described (see 2.3 and 2.4) and sterilized by UV radiation for $2 \mathrm{~h}$. Immediately afterwards, the specimens were placed in a 24-well plate and incubated with a-MEM (Biochrom, Berlin, Germany) containing $10 \%$ FBS and $1 \%$ PenStrep. Eluates were collected daily from day 1 to 7 and subsequently at days 14 , 21 and 28 . The eluates were frozen at $-20^{\circ} \mathrm{C}$ and stored in the freezer until use. Subsequently, each specimen was rinsed with $1 \mathrm{ml}$ PBS and fresh culture medium was added to the wells.

In the second part of the experiment, MC3T3-E1 cells (DSMZ ACC210, DSM, Braunschweig, Germany) were incubated with eluates obtained from the biomaterials and checked for cytotoxicity. Therefore, MC3T3-E1 cells were seeded into 96-well microtiter plates at densities of 10.000 cells/well and cultivated for $24 \mathrm{~h}$ under standard atmospheric conditions. After $24 \mathrm{~h}$ the cells were incubated with the collected eluates $(100 \mu \mathrm{l})$ for $2 \mathrm{~d}$ at $37^{\circ} \mathrm{C}$ under aerobic standard conditions. The test was repeated 8 times for each biomaterial specimen no matter if it contained PS ( $n=$ $8)$ or not $(n=8)$. Controls $(n=8)$ were incubated with $100 \mu$ cell culture medium, only. After $48 \mathrm{~h}$ of incubation, all cells were subjected to MTT viability assay (Roche, 
Mannheim, Germany) according to the manufacturers' instructions. The absorption of purple colored formazan was recorded in PBS using an absorbance spectrometer at $570 \mathrm{~nm}$ and cell viability was estimated as follows:

$$
\text { Viability }(\%)=100 \times(\text { absorption test-group/absorption } \text { control-group })
$$

\subsection{Cytotoxicity - direct contact}

MC3T3-E1 cells (DSMZ ACC210, DSM, Braunschweig, Germany) were cultivated in Dulbecco's modified Eagle's medium (DMEM) (Biochrom, Berlin, Germany) supplemented with $10 \%$ FCS, containing $50 \mathrm{U} \mathrm{ml}^{-1}$ of penicillin, $0.05 \mathrm{mg} \mathrm{ml}^{-1}$ of streptomycin at $37{ }^{\circ} \mathrm{C}$ under $5 \% \mathrm{CO}_{2}$ atmosphere. Cylindrical specimens $(5 \times 5 \mathrm{~mm}$, height $x$ diameter) of biomaterial BioM1 and BioM2 with and without PS were prepared and transferred each into a separate well of a 24 well cell culture plate. After sterilization of the specimens with UV radiation for $2 \mathrm{~h}, 25.000$ cells suspended in $1 \mathrm{ml}$ culture medium were seeded into each well covering the biomaterial specimens. The culture medium was renewed each second day. At day 4, the specimens were carefully transferred to microscopic slides and the cells were stained with $0.05 \mathrm{ml}$ of staining solution (final concentrations: $15 \mathrm{\mu g} \mathrm{ml}^{-1}$ fluorescein diacetate (FDA), $4 \mu \mathrm{g} \mathrm{ml}^{-1}$ GelRed $尺$ in PBS). Green and red fluorescence of the cells, respectively, was monitored using an Axiotech microscope (Carl Zeiss, Jena, Germany) equipped with filter sets 09 and 14. Photomicrographs were recorded using a CCD fluorescence microscope imager MP 5000 (Intas, Göttingen, Germany). Imaging was supported by Image-Pro Plus software (Media Cybernetics, Silver Spring, MD, USA). 


\subsection{Antimicrobial photodynamic activity}

The antimicrobial photodynamic activity of the biomaterials was tested on the oral pathogenic species Porphyromonas gingivalis (ATCC 33277) and Enterococcus faecalis (DMSZ 20376).

Each bacterial strain was grown in Schaedler fluide media $(0.1 \%$ Konakion $(\mathrm{wt} / \mathrm{vol}))$ (Oxoid Deutschland, Wesel, Germany) for $24 \mathrm{~h}$ under anaerobic standard conditions. Subsequently, the bacteria were pelleted by centrifugation and dissolved in PBS to an optical density (OD $546 \mathrm{~nm}$ ) of 0.05 .

Prior to testing, defined amounts (35 $\mu$ l) of monomeric BioM1 and BioM2 substituted with PS were transferred to 96-well microtiter plates and light-cured for $60 \mathrm{~s}$ using the dental curing light Polofil Lux® (Voco, Cuxhafen, Germany). Specimens of BioM1 and BioM2 without PS were arranged as controls.

The surfaces of the polymerized specimens were rinsed with distilled water and sterilized by treatment with ultraviolet radiation for $20 \mathrm{~min}$. Subsequently, $50 \mu \mathrm{l}$ of the respective bacterial solution was added on top of the polymerized material and the cells were sedimented by centrifugation (3500 rpm, $3 \mathrm{~min}$ ). Afterwards, all specimens were incubated for $1 \mathrm{~h}$ at $37^{\circ} \mathrm{C}$ under anaerobic standard conditions in the dark.

Irradiation of the specimens was performed by using a GaAs diode laser $(652 \mathrm{~nm}$, Ceralas PDT, CeramOptec, Bonn, Germany), operating in continuous mode. The respective microtiter plate was placed on a computer-controlled laser scanning stage and irradiated from above. The light from the laser device was guided by a flexible optical fiber (Medlight FD1, Medlight, Ecublens, Switzerland) equipped with a frontal light distributor. For efficient illumination of each well, the optical fiber was firmly attached to the laser scanning stage at a distance of $10 \mathrm{~mm}$ to the surface of the plate. Specimens were irradiated for $33 \mathrm{~s}$ either once $\left(1 \times 100 \mathrm{~J} / \mathrm{cm}^{2}\right)$ or twice $(2 \mathrm{x}$ $\left.100 \mathrm{~J} / \mathrm{cm}^{2}\right)$ with an interval of $3 \mathrm{~min}$. After irradiation, the bacterial solution $(50 \mu \mathrm{l})$ was collected from each well and mixed with $950 \mu \mathrm{PBS}$. Subsequently, dilution series from $10^{-1}$ to $10^{-5}$ were arranged and $100 \mu$ aliquots of each dilution were plated on sterile Schaedler agar (Oxoid, Wesel, Germany). After cultivation for 2 to 5 days under anaerobic standard conditions the number of colony forming units (CFU/ml) was determined by counting. For each specimen 10 runs were performed. 


\subsection{Statistical analysis}

The results of the mechanical characterization were analyzed by student's t-test. Significance in the antibacterial photodynamic assays was checked by applying the non-parametric Mann-Whitney-U-test. The level of significance was set to alpha = 0.05. For statistical analysis the PC program SPSS version 19 (IBM, Chicago, USA) was used. In subsequent figures an iconic star is shown to indicate statistically significant differences between groups. 


\section{Results}

In the present study, two in-situ curable biomaterials, BioM1 and BioM2 were prepared as support for photosensitizers potentially usable in photodynamic antimicrobial therapy.

\subsection{Monomer characterization}

The newly synthesized glycerol oligo-D,L-lactide- based tri-armed urethane methacrylate monomer (Figure 2) of BioM2 was structurally characterized by $I R,{ }^{1} \mathrm{H}$ NMR and ${ }^{13} \mathrm{C}$ NMR spectroscopy.

The ${ }^{1} \mathrm{H}$-NMR spectrum showed typical signals at $6.06 \mathrm{ppm}, 5.56 \mathrm{ppm}\left(\mathrm{C}=\mathrm{CH}_{2}\right)$ and $1.91 \mathrm{ppm}\left(\mathrm{CH}_{3}\right)$ of the methacrylate groups as well as $5.27 \mathrm{ppm}, 4.83-4.34 \mathrm{ppm}$ $(\mathrm{CH})$ and $1.56-1.52 \mathrm{ppm}\left(\mathrm{CH}_{3}\right)$ of lactide units. The signals of the glycerin starter were localized at $5.27 \mathrm{ppm}(\mathrm{CH}-\mathrm{O}), 4.34 \mathrm{ppm}$ and $4.19 \mathrm{ppm}$ for the $\mathrm{CH}_{2}-\mathrm{O}$ moiety. The $\mathrm{CH}_{2}$ groups in the neighborhood of the urethane bonds displayed proton signals at $4.26 \mathrm{ppm}$ and $3.47 \mathrm{ppm}$.

Complete urethane formation was confirmed by the absence of an $\mathrm{OH}$ absorption in the FT-IR spectra at $3300-3600 \mathrm{~cm}^{-1}$. The introduction of urethane methacrylate function into the tri-armed monomer is illustrated in the FT-IR spectrum by the appearance of the $\mathrm{N}-\mathrm{H}$ absorption at $3420 \mathrm{~cm}^{-1}$ and a $\mathrm{C}=\mathrm{C}$ stretching band of the methacrylate group at $1636 \mathrm{~cm}^{-1}$.

The glass transition temperature $(\mathrm{Tg})$ and the tangent delta of both tested materials are listed in Table 1. BioM1 showed a higher glass transition temperature $\left(111^{\circ} \mathrm{C}\right)$ compared to BioM2 $\left(31^{\circ} \mathrm{C}\right)$. Additional application of PS to BioM1 and BioM2 did not result in any significant change in the $\mathrm{Tg}$.

\subsection{Mechanical behavior}

For both biomaterials the compressive strength, flexural strength and compressive modulus of elasticity was estimated (Figures 4-6).

The results show that in specimens without PS, a mean compressive strength of 432.14 MPa was obtained for BioM1 and 517.86 MPa for BioM2. Addition of PS resulted in significant different compressive strengths. In detail, 311.73 MPa was measured for BioM1 + PS and 742.35 MPa for BioM2 + PS (Fig. 4). 
For BioM1 a flexural strength of 29.45 MPa was obtained. When PS was added to BioM1 the mean flexural strength decreased to $22.81 \mathrm{MPa}$, which was statistically not significant (Fig. 5). For BioM2, a mean flexural strength of $9.96 \mathrm{MPa}$ was measured. Application of PS to BioM2 caused no significant reduction in the flexural strength (7.58 MPa). By comparing both PS-containing materials, BioM1 + PS showed a significant greater flexural strength compared to BioM2 + PS.

However, the modulus of elasticity was almost identical for both materials without PS (Fig. 6). Incorporation of PS caused a significant drop in the elastic modulus from 519.88 to $318.85 \mathrm{MPa}(\mathrm{p}<0.05)$ in BioM1. By contrast, application of PS to BioM2 caused an increase in the elastic modulus from 335.19 to $406.23 \mathrm{MPa}$, which was statistically not significant.

In summary, additional application of PS to the polymeric base materials did not negatively influence the mechanical properties. Only in BioM1, incorporation of PS induced a significant decrease in the modulus of elasticity.

\subsection{Weight loss (degradation) in water.}

The results of the degradation study in distilled water at $70^{\circ} \mathrm{C}$ are presented in figure 9. During the entire examination period BioM1 without PS degraded by only $1.5 \%$ of weight. If PS was added to BioM1 a mean degradation of $4.8 \%$ was estimated. In contrast, BioM2 without PS lost weight by $66.8 \%$ within the first 28 days already, without any further degradation afterwards. If PS was added a loss in weight by 74.1 $\%$ was determined during the first 28 days of incubation without any further significant changes in weight any time after. 


\subsection{Cytotoxic behavior}

Beside their physical properties, the cytotoxic behavior of the materials w/o PS was also studied on MC3T3-E1 cells. The cells were incubated with collected eluates or cultivated in direct contact to the biomaterials.

Over a course of 28 days, no cytotoxic effects of the collected eluates were observed (Fig. 7). During the entire examination period, viability of the cells remained at high levels.

Cultivation of the MC3T3-E1 cells in direct contact to the materials (containing PS or not) did not cause any negative effect (Fig. 8). In the applied live/dead assay the vast majority of cells appeared in green fluorescence which indicates high integrity of the cell walls. Additionally, the cells showed a uniform growth pattern throughout the entire biomaterial surfaces.

In summary, none of the tested biomaterials, whether they contained PS (test-group) or not (control-group) showed any cytotoxic reaction towards MC3T3-E1 cells.

\subsection{Antimicrobial photodynamic activity}

Irradiation of the specimens with red laser light at $652 \mathrm{~nm}$ that additionally contained mTHPC caused significant microbial suppression (Figures 10,11). The results show that both tested bacterial strains were susceptible to the photodynamic reaction. Single irradiation $\left(100 \mathrm{~J} / \mathrm{cm}^{2}\right)$ of PS containing BioM1 caused suppression of $P$. gingivalis by 4 log-counts and induced total bacterial killing in case of BioM2 + PS (test-group). When laser light was applied twice $\left(2 \times 100 \mathrm{~J} / \mathrm{cm}^{2}\right) P$. gingivalis was eliminated completely within both materials (Fig. 10).

With E. faecalis (Figure 11), single irradiation of the materials + PS resulted in only minor bacterial suppression, which was not statistically significant. However, when the specimens were irradiated twice $\left(2 \times 100 \mathrm{~J} / \mathrm{cm}^{2}\right)$ bacterial reduction by $3.7 \mathrm{log}$ counts (BioM1 + PS) and 3.1 log-counts (BioM2 + PS) was observed. By contrast, irradiation of materials without PS did not result in any bacterial reduction of either $P$. gingivalis or E. faecalis. Furthermore, incubation of the PS containing biomaterials in the dark also caused no significant toxic effect. 


\section{Discussion}

The aim of the present study was to develop an innovative polymeric grafting material for periodontal regeneration. According to the clinical requirements, it was intended to design an easy to use material of sufficient mechanical stability with local antimicrobial activity that can be switched on at any time, on demand, apart from the action of antibiotics. Further, the materials should also be of high cytocompatibility and osteoinductive activity.

To the best of our knowledge, there is currently no grafting material available that meets all of these requirements. The present study focused on polymeric and hybrid materials because they have the most promising characteristics to integrate all the mentioned requirements [23]. Due to their chemical structure, polymers and polymeric composites are practicable and show biomechanical characteristics that are superior to many other grafting materials [24].

In a recent study, our group published data which showed that polymers based on poly(vinyl butyral-co-vinyl alcohol-co-vinyl acetate), functionalized oligolactone-based networks and urethane methacrylates have excellent cytocompatible properties [21]. Accordingly, the present study focused on urethane methacrylate-based starting materials; that is, urethane dimethacrylates and a tri-armed oligoester-urethane methacrylate. Normally, urethane dimethacrylate-based materials show rather low tendency to degrade. In our specific clinical applications, degradable materials are advantageous, so we incorporated oligoester units into the structure of BioM2 to modulate the rate of degradation. The polymerizable monomers were further enriched with a photoinitiator system and a mixture consisting the photosensitizer mTHPC and B-TCP (PS). Both biomaterials were then subjected to different tests in order to obtain detailed information about the mechanical behavior, degradation rate, cytotoxicity and antimicrobial photodynamic activity.

BioM1 was composed of different urethane dimethacrylates. The biomechanical properties of urethane dimethacrylates are highly influenced by the type of buildingblocks and the molecular structure in general. The additional appearance of rotatable ester bonds within the molecule, however, enhances the material's elastic behavior, although a dense polymeric network is formed during light-polymerization [25, 26]. Unlike monomethacrylates, dimethacrylates are often characterized by stronger hydrophobicity which is reflected by low water sorption [27]. The hydrophobic 
character of dimethacrylates was also evident in the present study. As expected, BioM1 exhibited a rather low degradation rate in water. By contrast, BioM2 incorporated a more hydrophilic PEG-extended UDMA monomer and oligoesterbased urethane methacrylate with potentially water-cleavable ester bindings. Over the course of 140 days the BioM1 material lost weight by only $4.7 \%$. BioM2 specimens without PS degraded by only $1.5 \%$. Compared to BioM2 which showed a degradation of $74.1 \%$, BioM1 can therefore considered a rather inert material.

In regenerative therapy and tissue engineering, various grafts composed of lactide polymers are already widely applied [28, 29]. Biomaterials manufactured from lactides are usually reabsorbed by the body to a high extent [30]. It is conceivable that inert materials like BioM1 + PS may be applied to defects where a long term spacer is needed [31, 32].

In the present study ß-TCP was additionally added to create pores of different dimensions. ß-TCP is also widely used in regenerative therapy and tissue engineering [33-37]. Because of their osteoinductive characteristics calcium phosphate cements are therefore often applied [38].

It is well known that the porosity of a grafted material has a great impact on the incorporation and subsequent stage of vascularization [39-41]. In detail, it was found that an additional application of ß-TCP increased neo vessel formation by 1.8 fold and also showed positive effects on the mechanical properties of synthetic grafting materials $[42,43]$.

In order to observe the impact of the photosensitizer / $ß$-TCP mixture (PS) on mechanical properties, the biomaterials were characterized for their compressive strength, flexural strength and modulus of elasticity. As shown by the results, additional application of PS in the polymeric material did not negatively influence the mechanical properties, except in the case of BioM1 where a significant reduction in the modulus of elasticity was apparent amongst specimens containing PS.

The mechanical tests revealed mean compressive strengths of $311.73 \mathrm{MPa}$ (BioM1 + PS) and 742.37 (BioM2 + PS), probably sufficient for the materials to resist normal masticatory forces [44].

In the three-point flexural tests, different strengths were recorded for both materials. BioM1 + PS showed a significant stronger resistance towards bending (22.81 MPa) compared to BioM2 + PS (7.58 MPa). Studies, however, have shown that there should be no significant discrepancy between the mechanical properties of the 
implanted material and the host tissue in order to achieve sufficient regeneration. If there are any mismatches, stress shielding and local bone resorptions are likely to occur [45].

As already mentioned, application of PS caused a significant reduction in the modulus of elasticity in BioM1. For the test-group specimens, values of $318.85 \mathrm{MPa}$ (BioM1 + PS) and 406.23 MPa (BioM2 + PS) were estimated. However, the results show that both biomaterials compared to the elastic modulus of natural alveolar bone with values as high as 9.6 GPa are less likely to resist elastic deformation [46].

The glass-transition temperatures $T_{g}$ of the materials were also evaluated. The glasstransition temperature marks the reversible transition from a hard and brittle state to a rubbery-like state in polymers. BioM1 + PS had a glass-transition temperature of 120 ${ }^{\circ} \mathrm{C}$ and BioM2 + PS of $35{ }^{\circ} \mathrm{C}$. Addition of PS only increased the glass-transition temperature by a few degrees compared to the materials without PS ( $9{ }^{\circ} \mathrm{C}$ for BioM1 and $4{ }^{\circ} \mathrm{C}$ for BioM2). If grafted into the body, fully polymerized BioM2 + PS with a $\mathrm{T}_{\mathrm{g}}$ of $35^{\circ} \mathrm{C}$ is more likely to have a rubbery consistency, whereas BioM1 + PS appears to be more solid. According to these results, BioM2 + PS might be grafted into smaller defects, while BioM1 + PS might be used in larger lesions.

Besides the biomechanical properties, the cytotoxicity of the materials was also evaluated. Incubation of the collected eluates with MC3T3-E1 cells did not cause any loss in viability. During the entire examination (28 days), the viability of the MC3T3E1 cells remained at very high levels (above 95\%). Even when the cells were cultivated in direct contact to the materials, no cytotoxic reaction was observed. As shown previously, the cytotoxicity of a polymeric material is highly influenced by the polymer type $[47,48]$.

In the present study the photosensitizer mTHPC was incorporated into the biomaterials to achieve antimicrobial activity upon illumination with red light at 652 $\mathrm{nm}$. Up to now, there are only a few reports available, where photosensitizers were used to create antimicrobial activity on the surface of solid materials [49, 50]. In photodynamic therapy, application of suitable light causes a photosensitizer to enter a triplet state which subsequently leads to the formation of highly reactive oxygen radicals that cause lethal damage to the microbes.

In the present study, the antimicrobial photodynamic action of the fabricated biomaterials was tested on both $P$. gingivalis and $E$. faecalis,. 
$P$. gingivalis is often associated with severe forms of periodontitis, causing inflammation and constant degeneration of alveolar bone [51, 52]. Bacteria of the periodontal region may also originate from infected dental pulps. Those combined lesions enable bacteria to spread across different environments. In this context, the grampositive bacterial species $E$. faecalis is of major concern. Primarily, the species is associated with refractory root canal infections, but can also affect the integrity of the apical periodontium causing osteolysis and abscesses. Because the species is able to inactivate neutrophil granulocytes and aggregates with periodontopathogenic Fusobacterium nucleatum, it is believed to play a distinct role in the pathogenesis of refractory and chronic forms of periodontitis [53, 54].

Our recent studies show that $E$. faecalis in planktonic solution and also in biofilm mode can be suppressed sufficiently by photodynamic treatment using $\operatorname{mTHPC}[5,7]$. In the present study, E. faecalis was more resistant to the photodynamic treatment compared to $P$. gingivalis. While $P$. gingivalis was killed completely after only one application of light (with BioM2), single irradiation of $E$. faecalis did not cause any significant reduction. However, if illumination was applied twice $\left(2 \times 100 \mathrm{~J} / \mathrm{cm}^{2}\right), E$. faecalis was reduced by $3.7 \log _{10}$ in BioM1 + PS and $3.1 \log _{10}$ in BioM2 + PS. By comparison to the control specimens, which did not contain PS, it was shown that application of laser light alone did not lead in any significant bacterial reduction. Therefore, the strong antibacterial effect can clearly be attributed to the photodynamic mechanism. A minor bacterial suppression caused by thermal heat during light application cannot be excluded, since the surface temperature during light application was not recorded. But earlier published data confirm that the rise in temperature caused by laser irradiation during aPDT doses not significantly influence bacterial life [5].

The results of the photodynamic setting can be compared to an article published by McCoy et al.. The group used different photosensitizers in combination with polymers. Irradiation of the specimens was performed using two $230 \mathrm{~W}$ halogen bulbs situated at a distance of $24 \mathrm{~cm}$ from the specimens, providing $1.34 \mathrm{~W}$ of light across the specimen surfaces, for two hours. The results showed that $S$. aureus was suppressed by 3.62 and E. coli by only $1.51 \mathrm{log}$ CFU/ml [49].

In another study, indocyanine green (ICG) was embedded into polyether type polyurethane with 0.015 or $0.105 w t \%$ of the specimens and the antibacterial photodynamic action was observed on methicillin-resistant Staphylococcus aureus, 
Escherichia coli, Pseudomonas aeruginosa and Staphylococcus epidermidis. Irradiation with $808 \mathrm{~nm}$ for $15 \mathrm{~min}$ (at energy density of $31.83 \mathrm{~J} / \mathrm{cm}^{2}$ ) caused reduction in $S$. aureus and $S$. epidermidis by $2 \log _{10}$ and $E$. coli and $P$. aeruginosa by $0.5 \log _{10}$ with the specimens of higher ICG content [50]. In the case of ICG, the antibacterial effect is mainly caused by thermal heating (photothermal therapy) rather than by a photodynamic mechanism what was observed in a recent study [6].

It can be concluded that the photodynamic antibacterial activity of the manufactured mTHPC containing biomaterials was superior to the results presented in the above mentioned studies. Only one single irradiation (irradiation time: $33 \mathrm{~s}$ ) caused total elimination of the gram-negative P. gingivalis (BioM2 + PS), while a 2-fold irradiation $(2 \times 33 s)$ reduced $P$. gingivalis completely within both biomaterials (BioM2 + PS and BioM1 + PS) and E. faecalis by $3.1 \log 10$ units (with BioM2 + PS) or $3.7 \log 10$ (with BioM1 + PS). It seems to be that there is actually no grafting material available exhibiting a more sufficient antimicrobial photodynamic activity.

The results show that our group successfully manufactured two different photodynamically active biomaterials with sufficient mechanical, cytocompatible and antimicrobial properties. The performance of the materials and their antimicrobial activity in vivo still needs to be investigated. 


\section{Conclusions}

Both tested biomaterials show excellent mechanical and cytocompatible properties. In addition, irradiation with red light at $652 \mathrm{~nm}$ caused strong antimicrobial behaviour. The manufactured biomaterials might enable clinicians to regenerate periodontal bone lesions more efficiently. If applied properly, the materials might also increase the primary stability of the afflicted teeth. Furthermore, the antimicrobial activity upon irradiation with light is useful to counter residual pathogens or to prevent the implant side from further microbial infections. Nevertheless, the performance of the materials still needs to be assessed in vivo.

\section{Acknowledgements}

This work was supported by the ministry of economy, technology and work of the German federal state of Thuringia and by the EU (EFRE co-financing) with joint research project No. 2007 VF 0012. Also, we greatly acknowledge all staff members of Innovent e. V. and biolitec research for their technical support. 


\section{References}

[1] Sigusch BW, Guntsch A, Pfitzner A, Glockmann E. Enhanced root planing and systemic metronidazole administration improve clinical and microbiological outcomes in a two-step treatment procedure. J Periodontol. 2005;76:991-7.

[2] van Winkelhoff AJ, Winkel EG. Antibiotics in periodontics: right or wrong? J Periodontol. 2009;80:1555-8.

[3] Reise M, Wyrwa R, Muller U, Zylinski M, Volpel A, Schnabelrauch M, et al. Release of metronidazole from electrospun poly(L-lactide-co-D/L-lactide) fibers for local periodontitis treatment. Dental materials : official publication of the Academy of Dental Materials. 2012;28:179-88.

[4] Yin R, Hamblin MR. Antimicrobial Photosensitizers: Drug Discovery Under the Spotlight. Current medicinal chemistry. 2015;22:2159-85.

[5] Kranz S, Guellmar A, Volpel A, Gitter B, Albrecht V, Sigusch BW. Photodynamic suppression of Enterococcus faecalis using the photosensitizer mTHPC. Lasers Surg Med. 2011;43:241-8.

[6] Kranz S, Huebsch M, Guellmar A, Voelpel A, Tonndorf-Martini S, Sigusch BW. Antibacterial photodynamic treatment of periodontopathogenic bacteria with indocyanine green and near-infrared laser light enhanced by Trolox(TM). Lasers Surg Med. 2015;47:350-60.

[7] Ossmann A, Kranz S, Andre G, Volpel A, Albrecht V, Fahr A, et al. Photodynamic killing of Enterococcus faecalis in dentinal tubules using mTHPC incorporated in liposomes and invasomes. Clinical oral investigations. 2015;19:373-84.

[8] Papastamou V, Nietzsch T, Staudte H, Orellana G, Sigusch BW. Photoinactivation of $F$. nucleatum and $P$. gingivalis using the ruthenium-based RD3 sensitizer and $a$ conventional halogen lamp. Arch Oral Biol. 2011;56:264-8.

[9] Pfitzner A, Sigusch BW, Albrecht V, Glockmann E. Killing of periodontopathogenic bacteria by photodynamic therapy. J Periodontol. 2004;75:1343-9.

[10] Sigusch BW, Engelbrecht M, Volpel A, Holletschke A, Pfister W, Schutze J. Fullmouth antimicrobial photodynamic therapy in Fusobacterium nucleatum-infected periodontitis patients. J Periodontol. 2010;81:975-81.

[11] Sigusch BW, Pfitzner A, Albrecht V, Glockmann E. Efficacy of photodynamic therapy on inflammatory signs and two selected periodontopathogenic species in a beagle dog model. J Periodontol. 2005;76:1100-5. 
[12] Voos AC, Kranz S, Tonndorf-Martini S, Voelpel A, Sigusch H, Staudte H, et al. Photodynamic antimicrobial effect of safranine $O$ on an ex vivo periodontal biofilm. Lasers Surg Med. 2014;46:235-43.

[13] Polimeni G, Xiropaidis AV, Wikesjo UM. Biology and principles of periodontal wound healing/regeneration. Periodontology 2000. 2006;41:30-47.

[14] Villar CC, Cochran DL. Regeneration of periodontal tissues: guided tissue regeneration. Dental clinics of North America. 2010;54:73-92.

[15] Chen FM, Zhang J, Zhang M, An Y, Chen F, Wu ZF. A review on endogenous regenerative technology in periodontal regenerative medicine. Biomaterials. 2010;31:7892-927.

[16] Sculean A, Nikolidakis D, Nikou G, Ivanovic A, Chapple IL, Stavropoulos A. Biomaterials for promoting periodontal regeneration in human intrabony defects: a systematic review. Periodontology 2000. 2015;68:182-216.

[17] Bottino MC, Thomas V, Schmidt G, Vohra YK, Chu TM, Kowolik MJ, et al. Recent advances in the development of GTR/GBR membranes for periodontal regeneration--a materials perspective. Dental materials : official publication of the Academy of Dental Materials. 2012;28:703-21.

[18] Dandu SR, Murthy KR. Multiple Gingival Recession Defects Treated with Coronally Advanced Flap and Either the VISTA Technique Enhanced with GEM 21S or Periosteal Pedicle Graft: A 9-Month Clinical Study. The International journal of periodontics \& restorative dentistry. 2016;36:231-7.

[19] Seshima F, Aoki H, Takeuchi T, Suzuki E, Irokawa D, Makino-Oi A, et al. Periodontal regenerative therapy with enamel matrix derivative in the treatment of intrabony defects: a prospective 2-year study. BMC research notes. 2017;10:256.

[20] Hagi TT, Laugisch O, Ivanovic A, Sculean A. Regenerative periodontal therapy. Quintessence international (Berlin, Germany : 1985). 2014;45:185-92.

[21] Ruediger T, Berg A, Guellmar A, Rode C, Schnabelrauch M, Urbanek A, et al. Cytocompatibility of polymer-based periodontal bone substitutes in gingival fibroblast and MC3T3 osteoblast cell cultures. Dental materials : official publication of the Academy of Dental Materials. 2012;28:e239-49.

[22] Berg A, Wyrwa R, Weisser J, Weiss T, Schade R, Hildebrand G, et al. Synthesis of Photopolymerizable Hydrophilic Macromers and Evaluation of Their Applicability as Reactive Resin Components for the Fabrication of Three-Dimensionally Structured 
Hydrogel Matrices by 2-Photon-Polymerization. Advanced Engineering Materials 2011;13:274-84.

[23] Yunus Basha R, Sampath Kumar TS, Doble M. Design of biocomposite materials for bone tissue regeneration. Mater Sci Eng C Mater Biol Appl. 2015;57:452-63.

[24] Yuan H, Fernandes H, Habibovic P, de Boer J, Barradas AM, de Ruiter A, et al. Osteoinductive ceramics as a synthetic alternative to autologous bone grafting. Proc Natl Acad Sci U S A. 2010;107:13614-9.

[25] Tanaka J, Hashimoto T, Stansbury JW, Antonucci JM, Suzuki K. Polymer properties on resins composed of UDMA and methacrylates with the carboxyl group. Dental materials journal. 2001;20:206-15.

[26] Van Landuyt KL, Snauwaert J, De Munck J, Peumans M, Yoshida Y, Poitevin A, et al. Systematic review of the chemical composition of contemporary dental adhesives. Biomaterials. 2007;28:3757-85.

[27] Sideridou ID, Karabela MM, Bikiaris DN. Aging studies of light cured dimethacrylate-based dental resins and a resin composite in water or ethanol/water. Dental materials : official publication of the Academy of Dental Materials. 2007;23:1142-9.

[28] Dreifke MB, Ebraheim NA, Jayasuriya AC. Investigation of potential injectable polymeric biomaterials for bone regeneration. Journal of biomedical materials research Part A. 2013;101:2436-47.

[29] Pilipchuk SP, Plonka AB, Monje A, Taut AD, Lanis A, Kang B, et al. Tissue engineering for bone regeneration and osseointegration in the oral cavity. Dental materials : official publication of the Academy of Dental Materials. 2015;31:317-38.

[30] Serino G, Rao W, lezzi G, Piattelli A. Polylactide and polyglycolide sponge used in human extraction sockets: bone formation following 3 months after its application. Clin Oral Implants Res. 2008;19:26-31.

[31] Kasaj A, Reichert C, Gotz H, Rohrig B, Smeets R, Willershausen B. In vitro evaluation of various bioabsorbable and nonresorbable barrier membranes for guided tissue regeneration. Head Face Med. 2008;4:22.

[32] Mota J, Yu N, Caridade SG, Luz GM, Gomes ME, Reis RL, et al. Chitosan/bioactive glass nanoparticle composite membranes for periodontal regeneration. Acta Biomater. 2012;8:4173-80.

[33] Irokawa D, Ota M, Yamamoto S, Shibukawa Y, Yamada S. Effect of beta tricalcium phosphate particle size on recombinant human platelet-derived growth 
factor-BB-induced regeneration of periodontal tissue in dog. Dental materials journal. 2010;29:721-30.

[34] Oi Y, Ota M, Yamamoto S, Shibukawa Y, Yamada S. Beta-tricalcium phosphate and basic fibroblast growth factor combination enhances periodontal regeneration in intrabony defects in dogs. Dental materials journal. 2009;28:162-9.

[35] Saito A, Saito E, Kuboki Y, Kimura M, Nakajima T, Yuge F, et al. Periodontal regeneration following application of basic fibroblast growth factor-2 in combination with beta tricalcium phosphate in class III furcation defects in dogs. Dental materials journal. 2013;32:256-62.

[36] Denry I, Kuhn LT. Design and characterization of calcium phosphate ceramic scaffolds for bone tissue engineering. Dental materials : official publication of the Academy of Dental Materials. 2016;32:43-53.

[37] Lee K, Weir MD, Lippens E, Mehta M, Wang P, Duda GN, et al. Bone regeneration via novel macroporous CPC scaffolds in critical-sized cranial defects in rats. Dental materials : official publication of the Academy of Dental Materials. 2014;30:e199-207.

[38] Fujikawa K, Sugawara A, Murai S, Nishiyama M, Takagi S, Chow LC. Histopathological reaction of calcium phosphate cement in periodontal bone defect. Dental materials journal. 1995;14:45-57.

[39] Dimitriou R, Jones E, McGonagle D, Giannoudis PV. Bone regeneration: current concepts and future directions. BMC Med. 2011;9:66.

[40] Giannoudis PV, Dinopoulos H, Tsiridis E. Bone substitutes: an update. Injury. 2005;36 Suppl 3:S20-7.

[41] Liu Q, Douglas T, Zamponi C, Becker ST, Sherry E, Sivananthan S, et al. Comparison of in vitro biocompatibility of NanoBone $((R))$ and BioOss $((R))$ for human osteoblasts. Clin Oral Implants Res. 2011;22:1259-64.

[42] Bonzani IC, Adhikari R, Houshyar S, Mayadunne R, Gunatillake P, Stevens MM. Synthesis of two-component injectable polyurethanes for bone tissue engineering. Biomaterials. 2007;28:423-33.

[43] Yanoso-Scholl L, Jacobson JA, Bradica G, Lerner AL, O'Keefe RJ, Schwarz EM, et al. Evaluation of dense polylactic acid/beta-tricalcium phosphate scaffolds for bone tissue engineering. Journal of biomedical materials research Part A. 2010;95:717-26. [44] Koc D, Dogan A, Bek B. Bite force and influential factors on bite force measurements: a literature review. Eur J Dent. 2010;4:223-32. 
[45] Koleganova VA, Bernier SM, Dixon SJ, Rizkalla AS. Bioactive glass/polymer composite materials with mechanical properties matching those of cortical bone. Journal of biomedical materials research Part A. 2006;77:572-9.

[46] Ho SP, Kurylo MP, Fong TK, Lee SS, Wagner HD, Ryder Ml, et al. The biomechanical characteristics of the bone-periodontal ligament-cementum complex. Biomaterials. 2010;31:6635-46.

[47] Wisniewska-Jarosinska M, Poplawski T, Chojnacki CJ, Pawlowska E, Krupa R, Szczepanska J, et al. Independent and combined cytotoxicity and genotoxicity of triethylene glycol dimethacrylate and urethane dimethacrylate. Mol Biol Rep. 2011;38:4603-11.

[48] Ren J, Zhao P, Ren T, Gu S, Pan K. Poly (D,L-lactide)/nano-hydroxyapatite composite scaffolds for bone tissue engineering and biocompatibility evaluation. J Mater Sci Mater Med. 2008;19:1075-82.

[49] McCoy CP, O'Neil EJ, Cowley JF, Carson L, De Baroid AT, Gdowski GT, et al. Photodynamic antimicrobial polymers for infection control. PLoS One. 2014;9:e108500.

[50] Perni S, Pratten J, Wilson M, Piccirillo C, Parkin IP, Prokopovich P. Antimicrobial properties of light-activated polyurethane containing indocyanine green. Journal of biomaterials applications. 2011;25:387-400.

[51] Ballini A, Cantore $S$, Farronato $D$, Cirulli N, Inchingolo $F$, Papa $F$, et al. PERIODONTAL DISEASE AND BONE PATHOGENESIS: THE CROSSTALK BETWEEN CYTOKINES AND PORPHYROMONAS GINGIVALIS. J Biol Regul Homeost Agents. 2015;29:273-81.

[52] Meka A, Bakthavatchalu V, Sathishkumar S, Lopez MC, Verma RK, Wallet SM, et al. Porphyromonas gingivalis infection-induced tissue and bone transcriptional profiles. Mol Oral Microbiol. 2010;25:61-74.

[53] Balaei-Gajan E, Shirmohammadi A, Abashov R, Agazadeh M, Faramarzie M. Detection of enterococcus faecalis in subgingival biofilm of patients with chronic refractory periodontitis. Med Oral Patol Oral Cir Bucal. 2010;15:e667-70.

[54] Sun J, Sundsfjord A, Song X. Enterococcus faecalis from patients with chronic periodontitis: virulence and antimicrobial resistance traits and determinants. Eur $\mathrm{J}$ Clin Microbiol Infect Dis. 2012;31:267-72. 


\begin{tabular}{lcc} 
Biomaterial & $\mathbf{T g}\left[{ }^{\circ} \mathrm{C}\right]$ & $\tan \Delta$ \\
\hline BioM1 & 111 & 0.27 \\
\hline BioM2 + PS & 120 & 0.20 \\
\hline BioM2 & 31 & 0.48 \\
\hline BioM2 + PS & 35 & 0.55
\end{tabular}

\section{Table 1:}

Glass transition temperature of the materials BioM1 and BioM2 with and without the mTHPC/ ß-TCP mixture (PS)

\section{Legends}

\section{Table 1:}

Glass transition temperature of the materials BioM1 and BioM2 with and without the mTHPC/ ß-TCP mixture (PS)

\section{Figure 1:}

Chemical structure of the urethane dimethacrylate isomers of UDMA (used in BioM1)

\section{Figure 2:}

Chemical structure of the glycerol oligo-D,L-lactide based tri-armed urethane methacrylate monomer (used in BioM2)

\section{Figure 3:}

Chemical structure of the photosensitizer mTHPC (Temoporfin) (adapted from www.ChemDrug.com)

\section{Figure 4:}

Compressive strength of BioM1 and BioM2 with and without PS. Each group comprised $n=15$ samples.

\section{Figure 5:}

Flexural strength of BioM1 and BioM2 with and without PS. Each group comprised $n$ $=15$ samples. 


\section{Figure 6:}

Modulus of elasticity of BioM1 and BioM2 with and without PS. Each group comprised $\mathrm{n}=15$ samples.

\section{Figure 7:}

Cytotoxicity of eluates collected from BioM1 and BioM2 with and without PS on MC3T3-E1 cells determined by MTT viability assay

\section{Figure 8:}

Live/dead assay using FDA (green fluorescence indicating viable cells) and GelRed® (red fluorescence indication nuclei of dead cells) in direct contact of BioM1 and BioM2 with and without PS to MC3T3-E1

\section{Figure 9:}

Weight loss of BioM1 and BioM2 with and without PS in water at $70{ }^{\circ} \mathrm{C}$

\section{Figure 10:}

Antimicrobial activity of BioM1 and BioM2 with and without PS upon irradiation with laser light $(652 \mathrm{~nm})$ on Porphyromonas gingivalis. Arrows show total bacterial elimination. Stars indicate statistically significant differences.

\section{Figure 11:}

Antimicrobial activity of BioM1 and BioM2 with and without PS upon illumination with laser light (652 nm) on Enterococcus faecalis. Stars indicate statistically significant differences. 
<smiles>C=C(C)C(=O)CCOC(=O)NCCCC(C)(C)CCNC(=O)OCCOC(=O)C(=C)C</smiles><smiles>C=C(C)C(=O)CCOC(=O)NCC(C)(C)CC(C)CCNC(=O)OCCOC(=O)C(=C)C</smiles>

Figure 1:

Chemical structure of the urethane dimethacrylate isomers of UDMA (used in BioM1)

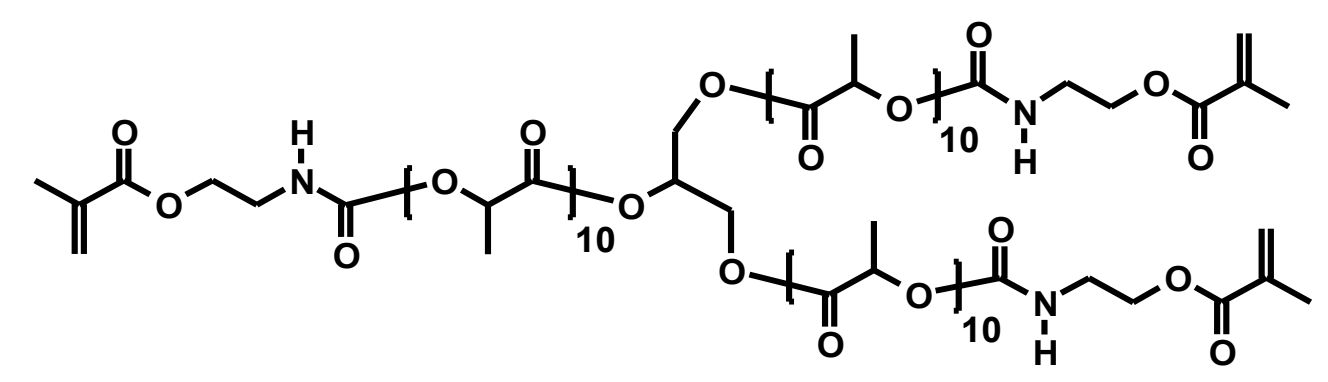

Figure 2:

Chemical structure of the glycerol oligo-D,L-lactide based tri-armed urethane methacrylate monomer (used in BioM2)

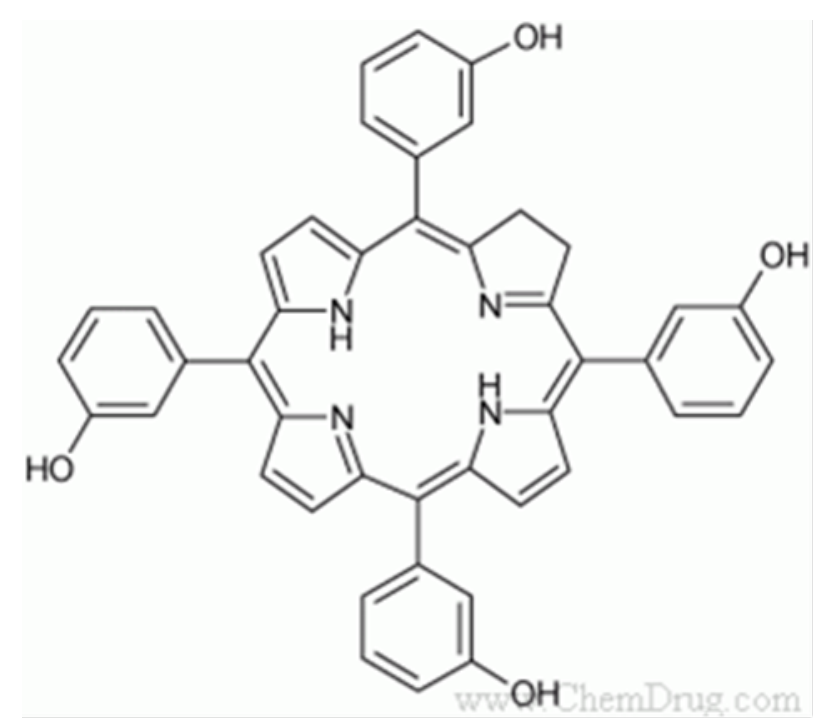

Figure 3:

Chemical structure of the photosensitizer mTHPC (Temoporfin) (adapted from www.ChemDrug.com) 


\section{Compressive Strengths}

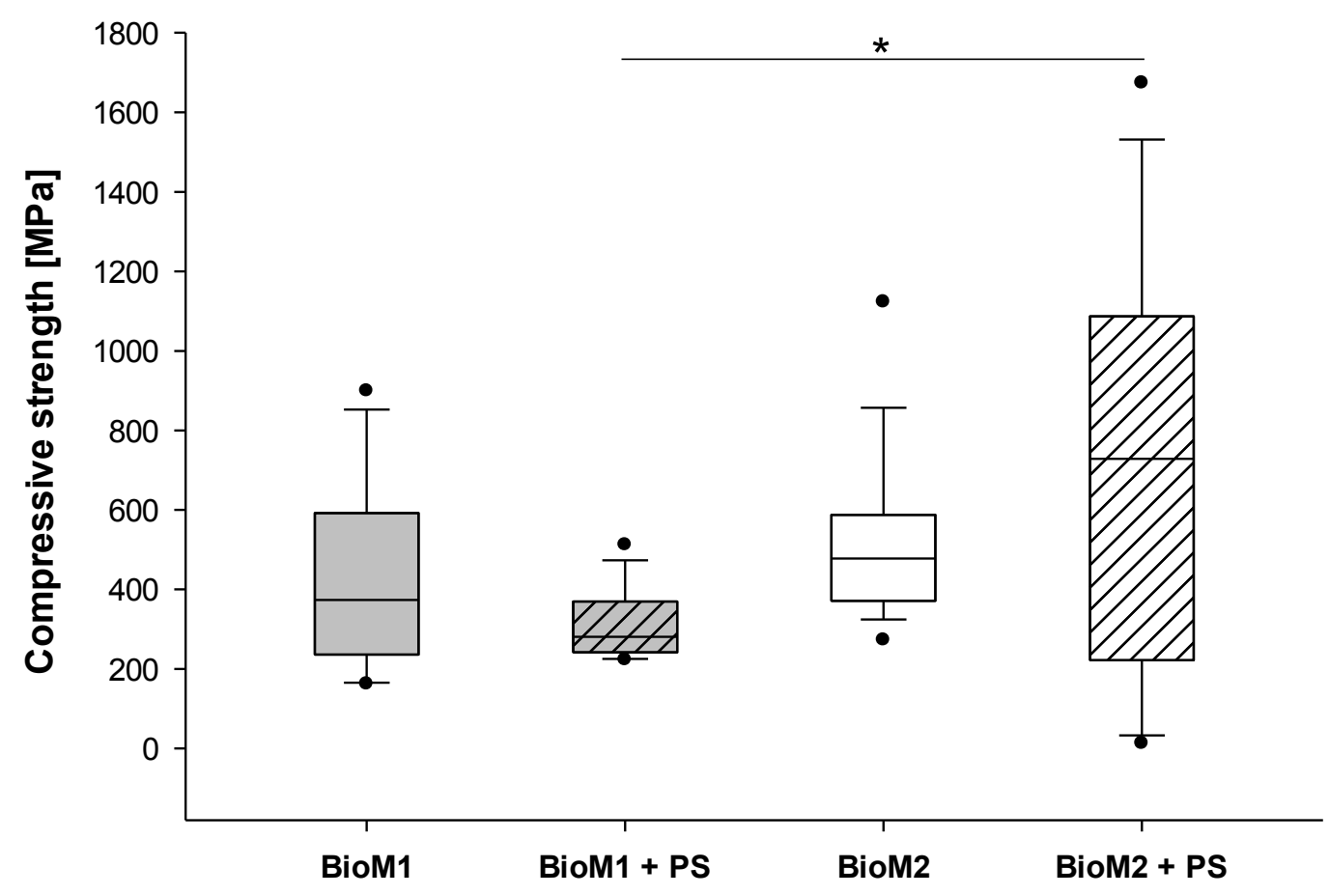

Figure 4:

Compressive strength of BioM1 and BioM2 with and without PS 


\section{Flexural Strengths}

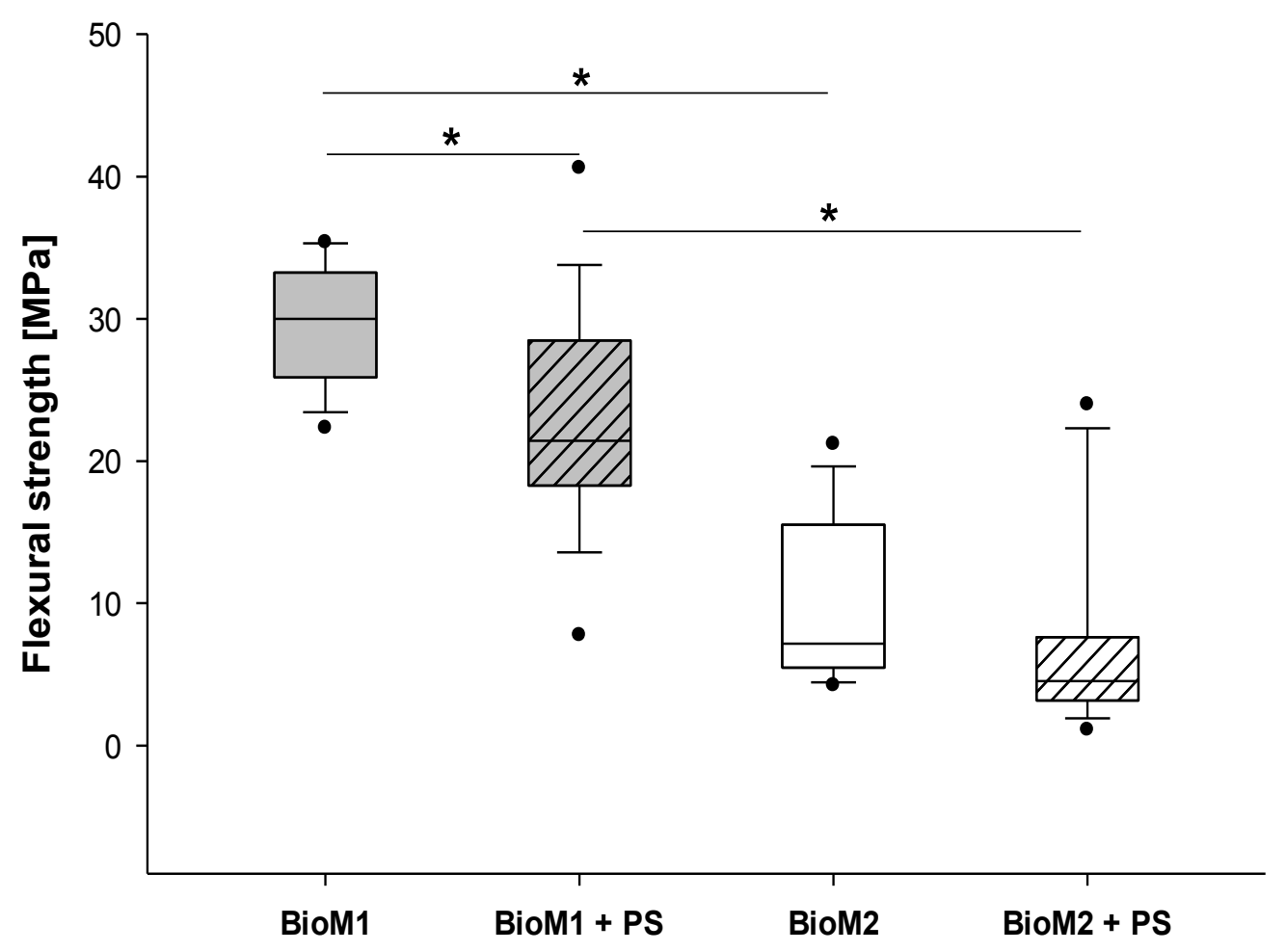

Figure 5:

Flexural strength of BioM1 and BioM2 with and without PS 


\section{Modulus of Elasticity in Compression}

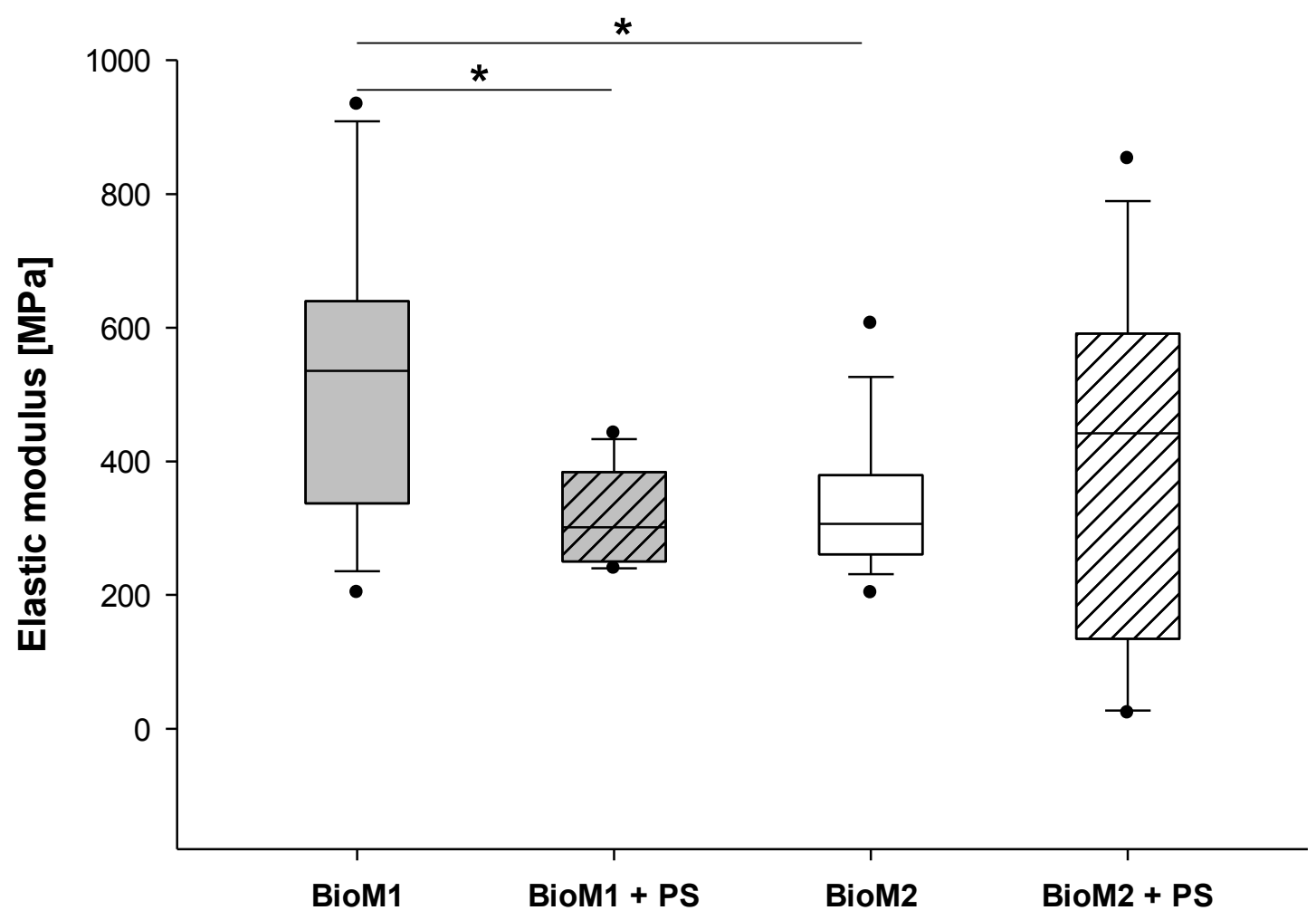

Figure 6:

Modulus of elasticity of BioM1 and BioM2 with and without PS 


\section{Cytotoxicity - Eluates}

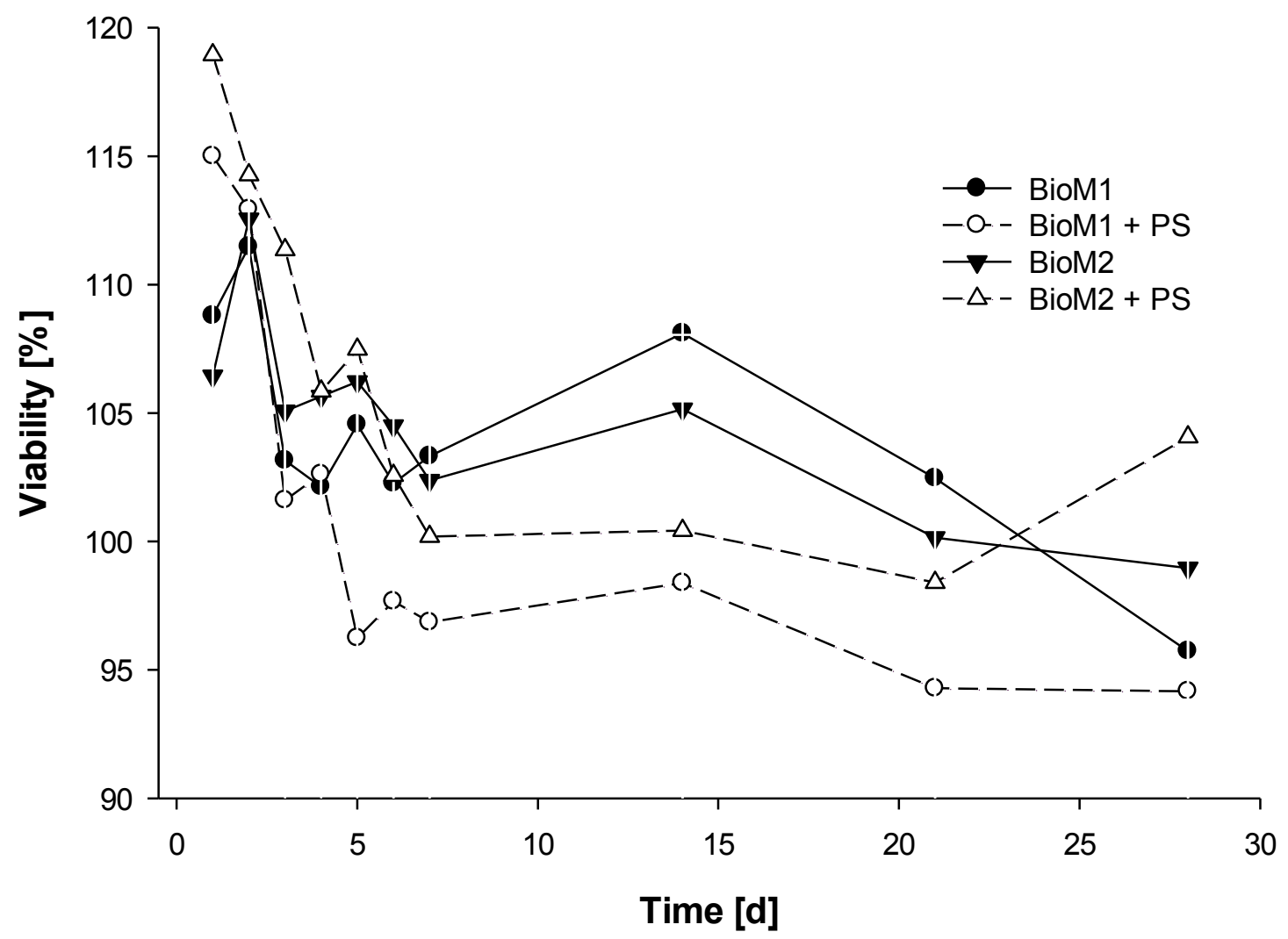

Figure 7:

Cytotoxicity of eluates collected from BioM1 and BioM2 with and without PS on MC3T3-E1 cells determined by MTT viability assay 


\section{Cytotoxicity - Direct contact}
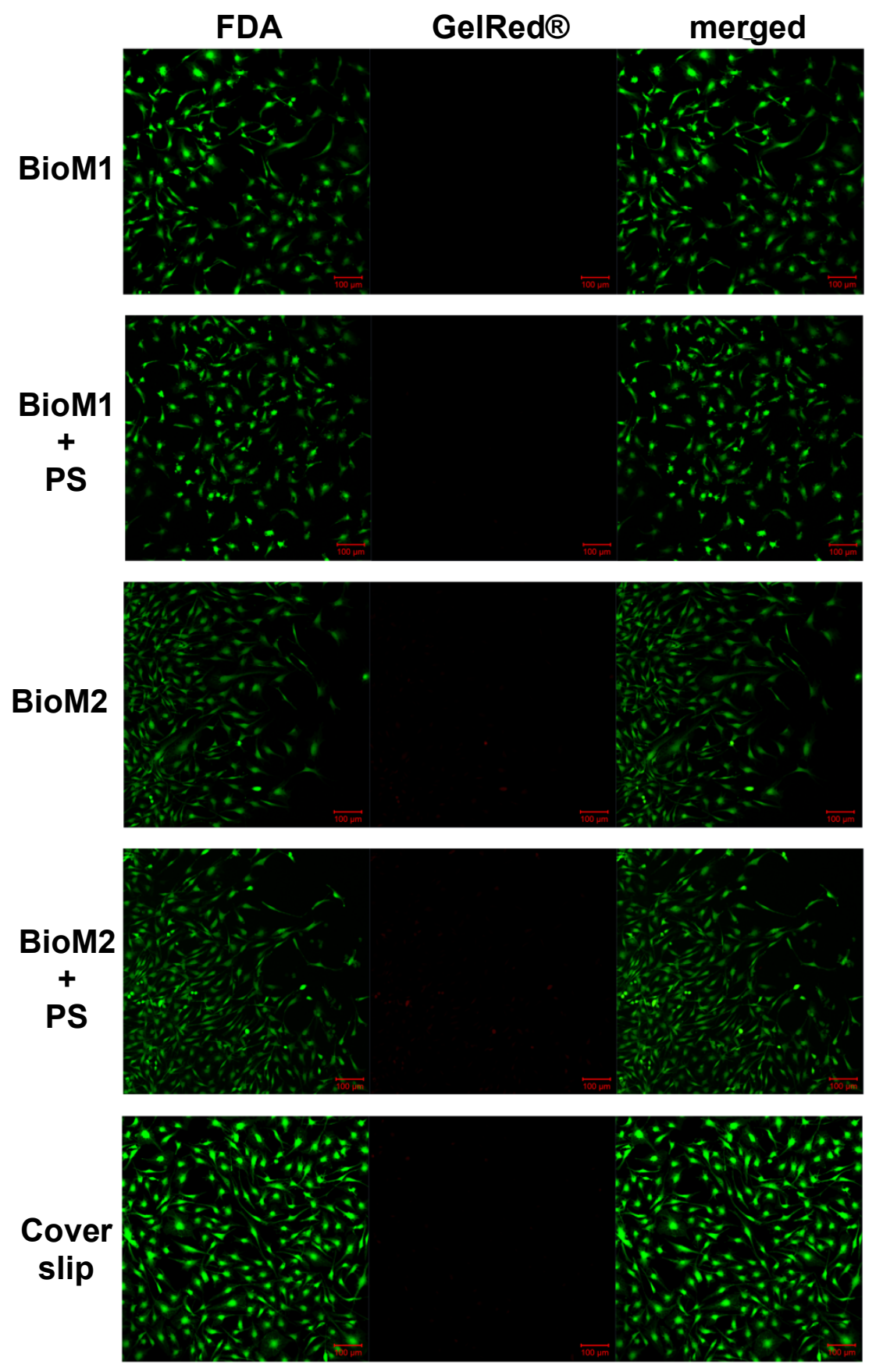

Figure 8:

Live/dead assay using FDA (green fluorescence indicating viable cells) and GelRed® (red fluorescence indication nuclei of dead cells) in direct contact of BioM1 and BioM2 with and without PS to MC3T3-E1 


\section{Degradation in Water $\left(70^{\circ} \mathrm{C}\right)$}

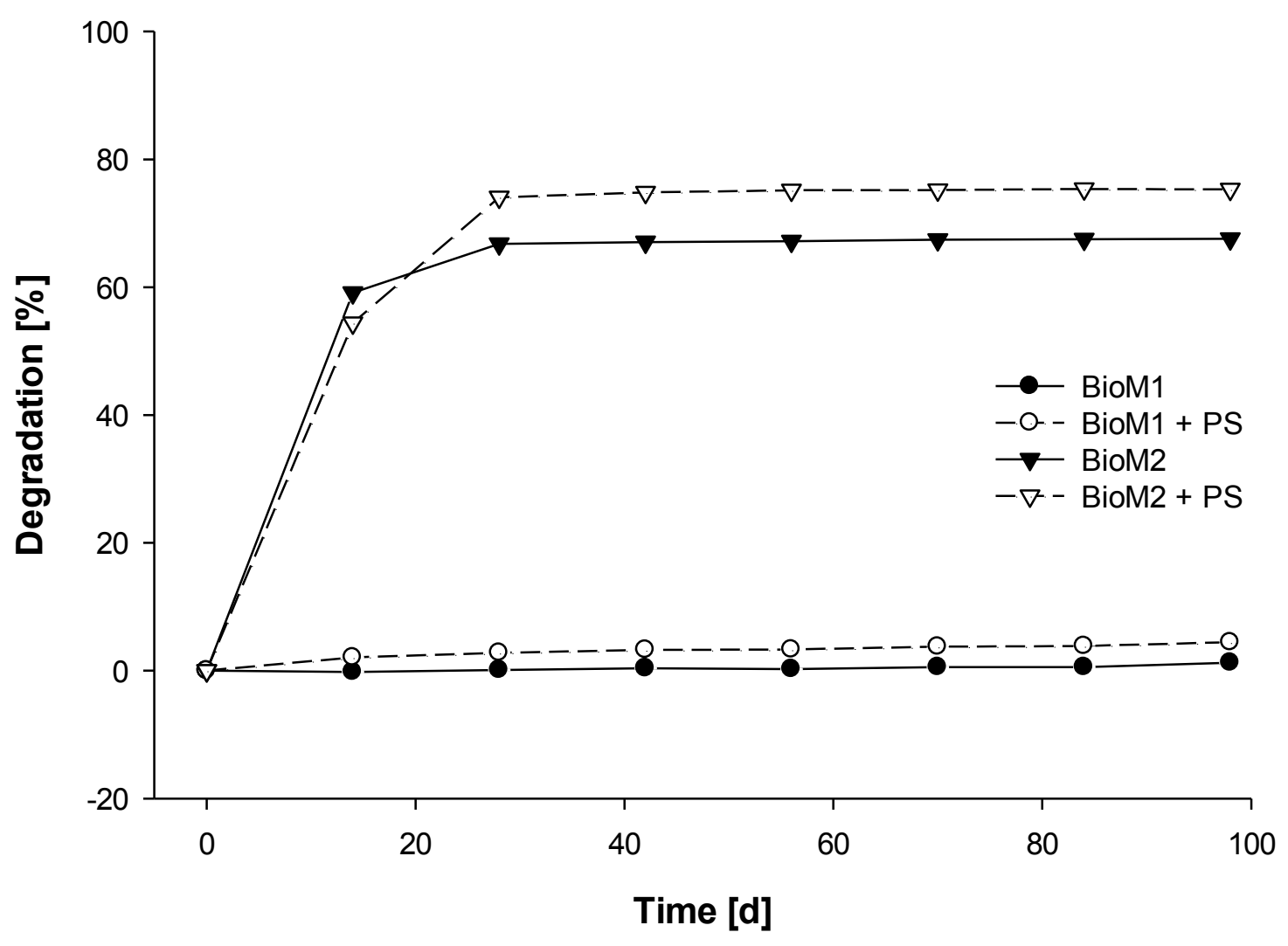

Figure 9:

Weight loss of BioM1 and BioM2 with and without PS in water at $70{ }^{\circ} \mathrm{C}$ 
Photodynamic activity - Porphyromonas gingivalis

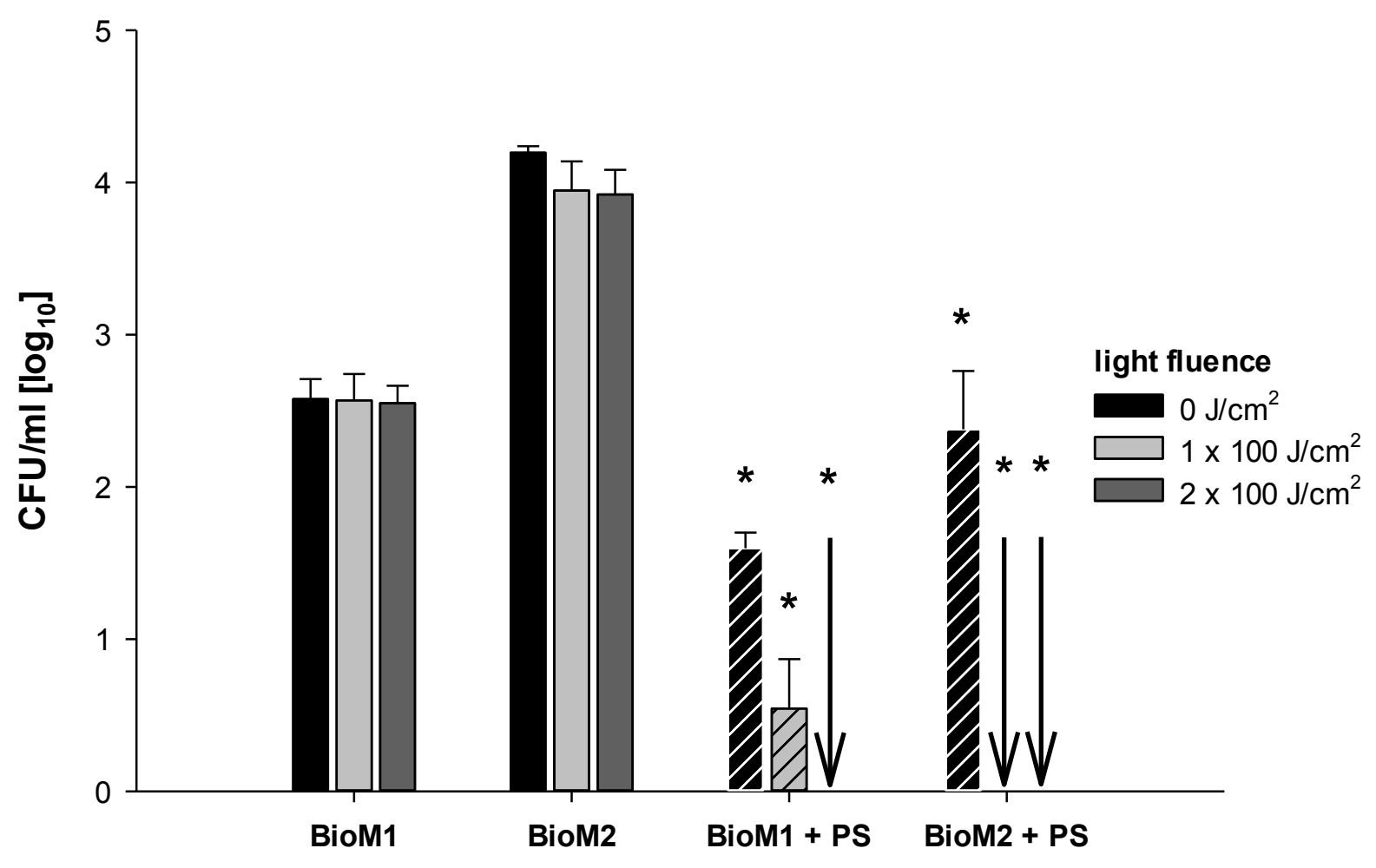

Figure 10:

Antimicrobial activity of BioM1 and BioM2 with and without PS upon irradiation with laser light $(652 \mathrm{~nm})$ on Porphyromonas gingivalis. Arrows show total bacterial elimination. Stars indicate statistically significant differences. 


\section{Photodynamic activity - Enterococcus faecalis}

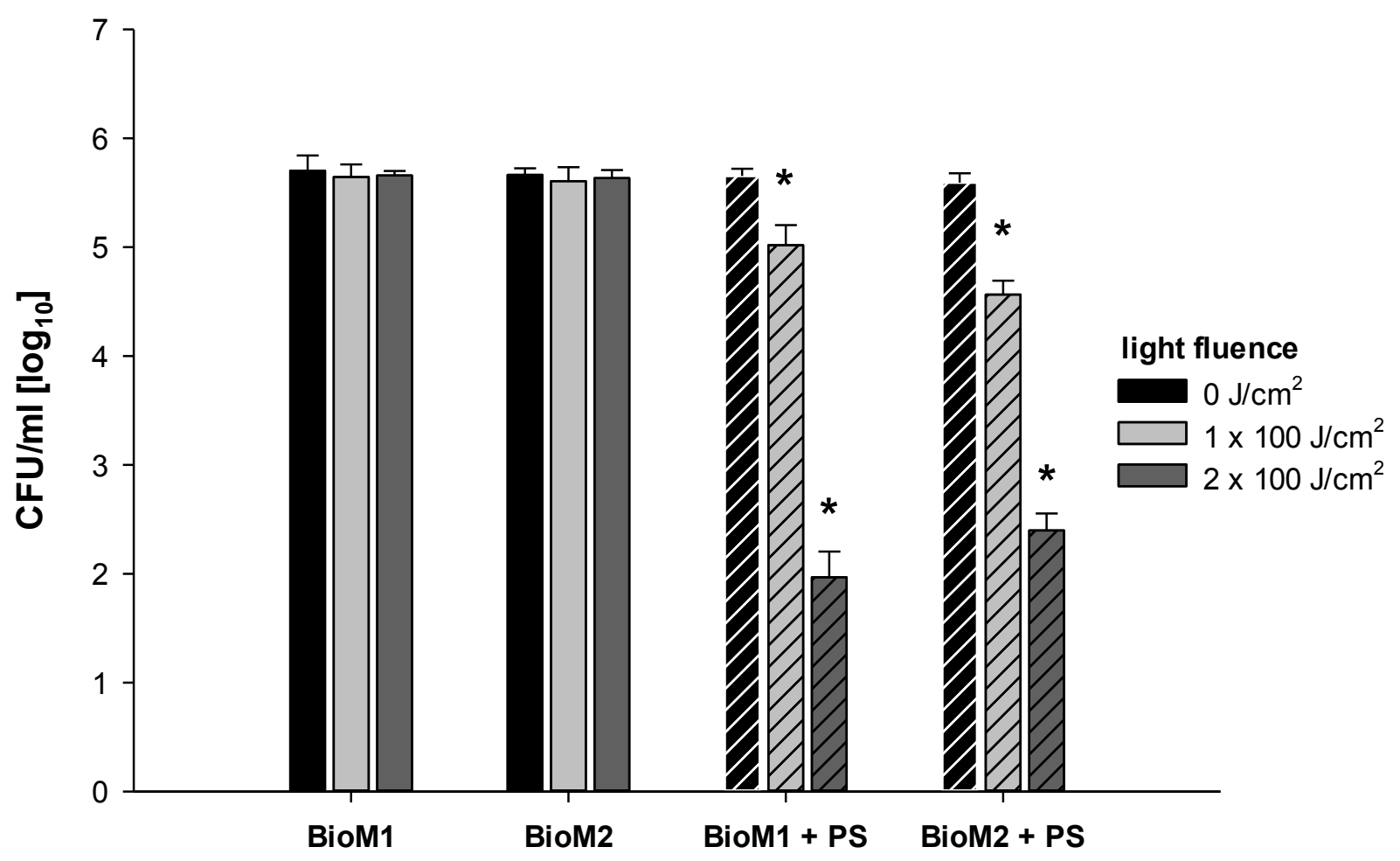

Figure 11:

Antimicrobial activity of BioM1 and BioM2 with and without PS upon illumination with laser light $(652 \mathrm{~nm})$ on Enterococcus faecalis. Stars indicate statistically significant differences. 